\title{
Scrubbing Masks Magmatic Degassing During Repose at Cascade-Range and Aleutian-Arc Volcanoes
}

By Robert B. Symonds ${ }^{1}$, Cathy J. Janik ${ }^{2}$, William C. Evans ${ }^{2}$, Beatrice E. Ritchie ${ }^{3}$, Dale Counce $^{4}$, Robert J. Poreda ${ }^{5}$, and Mark Iven ${ }^{1}$

Open-File Report 03-435

2003

This report is preliminary and has not been reviewed for conformity with U.S. Geological Survey editorial standards or with the North American Stratigraphic Code. Any use of trade, product or firm names is for descriptive purposes only and does not imply endorsement by the U.S. Government.

\section{U. S. DEPARTMENT OF THE INTERIOR U. S. GEOLOGICAL SURVEY}

${ }^{1}$ U.S. Geological Survey, Cascades Volcano Observatory, 5400 MacArthur Blvd., Vancouver, WA 98661

${ }^{2}$ U. S. Geological Survey, 345 Middlefield Road, Menlo Park, CA 94025

${ }^{3}$ Department of Geology, Portland State University, P.O. Box 751, Portland, OR 97207

${ }^{4}$ Los Alamos National Laboratory, Los Alamos, NM 87545

${ }^{5}$ Department of Earth and Environmental Science, 227 Hutchison Hall, University of Rochester, Rochester, NY 14627 


\begin{abstract}
Between 1992 and 1998, we sampled gas discharges from $\leq 173^{\circ} \mathrm{C}$ fumaroles and springs at 12 quiescent but potentially restless volcanoes in the Cascade Range and Aleutian Arc (CRAA) including Mount Shasta, Mount Hood, Mount St. Helens, Mount Rainier, Mount Baker, Augustine Volcano, Mount Griggs, Trident, Mount Mageik, Aniakchak Crater, Akutan, and Makushin. For each site, we collected and analyzed samples to characterize the chemical $\left(\mathrm{H}_{2} \mathrm{O}\right.$, $\left.\mathrm{CO}_{2}, \mathrm{H}_{2} \mathrm{~S}, \mathrm{~N}_{2}, \mathrm{CH}_{4}, \mathrm{H}_{2}, \mathrm{HCl}, \mathrm{HF}, \mathrm{NH}_{3}, \mathrm{Ar}, \mathrm{O}_{2}, \mathrm{He}\right)$ and isotopic $\left(\delta^{13} \mathrm{C}\right.$ of $\mathrm{CO}_{2},{ }^{3} \mathrm{He} /{ }^{4} \mathrm{He},{ }^{40} \mathrm{Ar} /{ }^{36} \mathrm{Ar}$, $\delta^{34} \mathrm{~S}, \delta^{13} \mathrm{C}$ of $\mathrm{CH}_{4}, \delta^{15} \mathrm{~N}$, and $\delta \mathrm{D}$ and $\delta^{18} \mathrm{O}$ of water) compositions of the gas discharges, and to create baseline data for comparison during future unrest. The chemical and isotopic data show that these gases contain a magmatic component that is heavily modified from scrubbing by deep hydrothermal $\left(150^{\circ}-350^{\circ} \mathrm{C}\right.$ ) water (primary scrubbing) and shallow meteoric water (secondary scrubbing). The impact of scrubbing is most pronounced in gas discharges from bubbling springs; gases from boiling-point fumaroles and superheated vents show progressively less impact from scrubbing. The most effective strategies for detecting gas precursors to future CRAA eruptions are to measure periodically the emission rates of $\mathrm{CO}_{2}$ and $\mathrm{SO}_{2}$, which have low and high respective solubilities in water, and to monitor continuously $\mathrm{CO}_{2}$ concentrations in soils around volcanic vents. Timely resampling of fumaroles can augment the geochemical surveillance program by watching for chemical changes associated with drying of fumarolic pathways (all CRAA sites), increases in gas geothermometry temperatures (Mount Mageik, Trident, Mount Baker, Mount Shasta), changes in $\delta^{13} \mathrm{C}$ of $\mathrm{CO}_{2}$ affiliated with magma movement (all CRAA site), and increases in ${ }^{3} \mathrm{He} /{ }^{4} \mathrm{He}$ coupled with intrusion of new magma (Mount Rainier, Augustine Volcano, Makushin, Mount Shasta). Repose magmatic degassing may discharge substantial amounts of $\mathrm{S}$ and $\mathrm{Cl}$ into the edifices of Mount Baker and several other CRAA volcanoes that is trapped by primary and secondary scrubbing. The consequent acidic fluids produce ongoing alteration in the 0.2 - to 3-km-deep hydrothermal systems and in fields of boiling-point fumaroles near the surface. Such alteration may influence edifice stability and contribute to the formation of more-hazardous cohesive debris flows. In particular, we recommend further investigation of the volume, extent, and hazards of hydrothermal alteration at Mount Baker. Other potential hazards associated with the CRAA volcano hydrothermal systems include hydrothermal eruptions and, for deeper systems intruded by magma, deep-seated edifice collapse.
\end{abstract}

\title{
INTRODUCTION
}

The Cascade Range, related to subduction of the Juan de Fuca plate beneath the North American plate, forms a 1200-km-long arc that extends from British Columbia to northern California. The much longer Aleutian Arc in Alaska extends $2500 \mathrm{~km}$ from Hayes volcano in the east to Buldir in the west and results from subduction of the Pacific plate beneath the North American plate. The U.S. Geological Survey (USGS) is charged with providing timely warnings of future volcanic activity at over 60 potentially restless volcanoes in the Cascade Range and Aleutian Arc (CRAA). In 1992, as part of the USGS's overall geophysical and geochemical monitoring effort, we began sampling the gas discharges from 12 quiescent but potentially restless CRAA volcanoes (Figure 1) to characterize the compositions and origins of these gases, and to create baseline data for comparison during future unrest. 
Our data show that these $\leq 173^{\circ} \mathrm{C}$ discharges are dominated by meteoric water, $\mathrm{CO}_{2}$, and $\mathrm{H}_{2} \mathrm{~S}$. In contrast, high-temperature $\left(>500^{\circ} \mathrm{C}\right)$ magmatic gases (HTMG) from convergent-plate volcanoes contain magmatic water and substantial $\mathrm{CO}_{2}, \mathrm{SO}_{2}$, and $\mathrm{HCl}$ (Giggenbach, 1992; Symonds and others, 1994; Giggenbach, 1996). Despite the apparent differences between the CRAA gases and HTMG, here we use thermochemical modeling (Symonds and others, 2001), evidence for subsurface heat, and a large body of chemical and isotopic data to demonstrate that these hydrothermal gases are mostly scrubbed HTMG (i.e., HTMG that reacted with large but variable amounts of liquid consisting mostly of meteoric water).

Scrubbing encompasses all processes that reduce emissions during reactions between HTMG, water, and sometimes rock, including dissolution into the aqueous phase (e.g., hydrolysis) and formation of precipitates (e.g., sulfur, sulfides, fluorides, sulfates) from gaswater or gas-water-rock reactions (Symonds and others, 2001). The concept of scrubbing, developed to explain low $\mathrm{SO}_{2}$ emissions before and between the 1992 eruptions of Crater Peak at Mount Spurr (Doukas and Gerlach, 1995), builds on a large body of previous work. Economic geologists and geothermalists have long supported the idea that hydrothermal systems absorb HTMG, producing acidic fluids that promote hydrothermal alteration and mineralization (Holland, 1965; Burham, 1979; Brimhall and Ghiorso, 1983; Armannsson and others, 1982; Hedenquist and Lowenstern, 1994). In particular, hydrolysis of $\mathrm{SO}_{2}$ produces $\mathrm{SO}_{4}{ }^{2-}(\mathrm{aq}), \mathrm{H}_{2} \mathrm{~S}_{(\mathrm{aq})}$, elemental sulfur, and $\mathrm{H}^{+}$(aq), although $\mathrm{H}_{2} \mathrm{~S}_{(\mathrm{aq})}$ can be consumed by reacting with $\mathrm{Fe}^{2+}$ (aq) to form pyrite (Holland, 1965; Armannsson and others, 1982). Recently, volcanologists have even shown that selective absorption of the more water-soluble species in $\mathrm{HTMG}$ (e.g., $\mathrm{SO}_{2}$ and $\mathrm{HCl}$ ) can produce some of the chemical variation in $>200^{\circ} \mathrm{C}$ volcanic gases (Giggenbach, 1996; Giggenbach and others, 1990; Fischer and others, 1996; Fischer and others, 1997).

However, by linking hydrolysis and precipitation processes under one umbrella, scrubbing provides a fundamentally new way of thinking of low-temperature volcanichydrothermal gases as part of the continuum of reaction products between HTMG and water. New thermochemical modeling (Symonds and others, 2001) shows that scrubbing reactions with water cause $\mathrm{H}_{2} \mathrm{O}-\mathrm{CO}_{2}-\mathrm{SO}_{2}-\mathrm{HCl}$-dominated $\mathrm{HTMG}$ to evolve to $\mathrm{H}_{2} \mathrm{O}-\mathrm{CO}_{2}-\mathrm{H}_{2} \mathrm{~S}$-dominated gases (with meteoric-magmatic water and magmatic $\mathrm{C}$ and $\mathrm{S}$ ). These modifications are the result of hydrolysis and sulfur precipitation reactions that consume most of the $\mathrm{SO}_{2}$ and $\mathrm{HCl}$, produce small amounts of $\mathrm{H}_{2} \mathrm{~S}$, and have little affect on $\mathrm{CO}_{2}$ (Doukas and Gerlach, 1995; Symonds and others, 2001). Scrubbing in concert with significant water-rock reaction removes all species except $\mathrm{CO}_{2}$ (Symonds and others, 2001). By demonstrating that the CRAA gases are scrubbed HTMG and therefore part of the continuum of reaction products between HTMG and water helps provide insight on potential gas precursors during future unrest and on hydrothermal hazards at CRAA volcanoes.

\section{SAMPLING AND ANALYTICAL METHODS}

During 1992-8, R. Symonds and B. Ritchie made two to six site visits to each volcano, except for Akutan and Makushin (only sampled in 1995), to sample the hottest or most vigorous summit or flank fumaroles. In some cases, only springs effervescing $\mathrm{CO}_{2}$ (soda springs) or bubbling acidic pools are available to sample. The gas-sampling sites (from southeast to northwest in Figure 1) include Mount Shasta (bubbling acidic hot pool near summit), Mount Hood (3 boiling-point fumaroles at Crater Rock and Devils Kitchen near summit), Mount St. Helens (boiling-point fumarole on September 1984 lobe of lava dome), Mount Rainier (2 cold 
soda springs at Longmire near base of southern flank), Mount Baker (3 superheated fumaroles in Sherman Crater), Augustine Volcano (boiling-point fumarole on 1986 dome), Mount Griggs ( 2 boiling-point summit fumaroles and 3 superheated flank fumaroles), Trident (boiling-point fumaroles on southeastern flank of pre-1963 edifice), Mount Mageik (4 superheated fumaroles in summit crater), Aniakchak Crater (cold soda spring on southwestern shore of Surprise Lake in caldera), Akutan (3 summit and 1 flank boiling-point fumaroles, and one hot soda spring at the base), and Makushin (boiling-point flank fumaroles in Glacier and Makushin Valleys).

At each site, they collected several gas subsamples for later analysis for bulk-gas composition, $\mathrm{C}$ isotopes, noble-gas isotopes, and, occasionally, $\delta \mathrm{D}$ and $\delta^{18} \mathrm{O}$ of water. To sample fumaroles, a Ti tube was inserted into the vent and attached to a dewared tube that minimizes condensation; this apparatus was connected to the sampling bottle with a short piece of silicone rubber (Symonds and others, 1994). Bubbling-springs and pools were sampled using a funnel attached to a short piece of Tygon tubing (Fahlquist and Janik, 1992). Utmost care was taken in all sampling to avoid air contamination.

Between 1992 and 1998, 113 bulk-gas subsamples were collected in evacuated bottles partly filled with $4 \mathrm{~N} \mathrm{NaOH}$ solution (Fahlquist and Janik, 1992). Analytical work was performed by M. Iven in 1992, M. Thompson in 1993-4, the Thermochem Company in 1995, and C. Janik and D. Counce in 1996-8. In general, these subsamples were analyzed by gas chromatography $\left(\mathrm{H}_{2}, \mathrm{CH}_{4}, \mathrm{~N}_{2}, \mathrm{O}_{2}, \mathrm{Ar}, \mathrm{He}\right.$ ), ion chromatography (total $\mathrm{S}, \mathrm{HCl}, \mathrm{HF}$ ), titration or manometric methods $\left(\mathrm{CO}_{2}\right)$, selective-ion electrode $\left(\mathrm{NH}_{3}\right)$, and gravimetric methods $\left(\mathrm{H}_{2} \mathrm{O}\right)$ (Fahlquist and Janik, 1992; Trujillo and others, 1987). Total $\mathrm{S}$ is reported as $\mathrm{H}_{2} \mathrm{~S}$ based on the dominance of $\mathrm{H}_{2} \mathrm{~S}$ and the absence of $\mathrm{SO}_{2}$ in concomitant dry gas analyses (see below). C. Janik and D. White also analyzed the 1996 samples for $\delta^{34} S$ of total $S$; analytical precision on the $\delta^{34} S$ values is \pm 0.2 per mil.

To quality-assure the analytical results from the five different laboratories, we compared (1) analyses of duplicate bulk-gas subsamples collected simultaneously from the same vent, (2) dry-gas analyses of bulk-gas subsamples with dry-gas analyses from C-isotope and noble-gas subsamples (see below) collected concurrently from the same vent, and (3) analyses of bulk-gas subsamples collected from the same vent but on different dates to check for unreasonable changes in analyzed gas composition. Our evaluation shows that the bulk-gas analyses for the 1992 and 1996-8 samples display excellent agreement with the concurrent dry-gas analyses, although septum leaks produced small amounts of air contamination in some bulk-gas samples. Sampling and analytical precision on duplicate samples is generally better than $\pm 0.1 \%$ for $\mathrm{H}_{2} \mathrm{O}$, $\pm 5 \%$ for $\mathrm{CO}_{2}$ and $\mathrm{H}_{2} \mathrm{~S}, \pm 10 \%$ for $\mathrm{H}_{2}$ and $\mathrm{CH}_{4}, \pm 50 \%$ for $\mathrm{HCl}$, and $\pm 30 \%$ for all other species. Higher precision values for $\mathrm{N}_{2}, \mathrm{O}_{2}$, Ar, and He reflect small but variable amounts of air contamination in duplicate samples. The high precision values for $\mathrm{HCl}$ probably indicate variable amounts of condensation in the sampling apparatus or scrubbing in the vent, which is more serious for samples from boiling-point fumaroles; $\mathrm{HCl}$ precision is generally better than $\pm 10 \%$ for samples from $>110^{\circ} \mathrm{C}$ superheated vents. The 1995 bulk-gas analyses are also of decent quality, although they bear high detection limits for $\mathrm{HCl}$ and have similar aircontamination problems. Unfortunately, the 1993-4 bulk-gas analyses suffer from several analytical errors and will not be considered further in this study.

Between 1994 and 1998, 37 C-isotope subsamples were collected in evacuated bottles. W. Evans analyzed these subsamples using mass spectrometry for $\delta^{13} \mathrm{C}_{\text {of }} \mathrm{CO}_{2}, \delta^{13} \mathrm{C}_{\text {of }} \mathrm{CH}_{4}$, and $\delta^{15} \mathrm{~N}$ of $\mathrm{N}_{2}$, and gas chromatography for dry-gas composition $\left(\mathrm{CO}_{2}, \mathrm{H}_{2} \mathrm{~S}, \mathrm{H}_{2}, \mathrm{CH}_{4}, \mathrm{~N}_{2}, \mathrm{O}_{2}, \mathrm{Ar}, \mathrm{He}\right.$, $\mathrm{C}_{2} \mathrm{H}_{6}, \mathrm{CO}, \mathrm{SO}_{2}$ ). Most samples have less than $0.5 \%$ air contamination. Analytical precision is 
\pm 0.1 per mil for $\delta^{13} \mathrm{C}$ of $\mathrm{CO}_{2}, \pm 0.5$ per mil for $\delta^{13} \mathrm{C}$ of $\mathrm{CH}_{4}$, and \pm 0.2 per mil for $\delta^{15} \mathrm{~N}$ of $\mathrm{N}_{2}$. During the same period, 31 noble-gas subsamples were collected in leak-resistant bottles made of Corning-1720 glass and fitted with vacuum stopcocks. R. Poreda analyzed these subsamples for dry-gas composition $\left(\mathrm{CO}_{2}+\mathrm{H}_{2} \mathrm{~S}, \mathrm{CH}_{4}, \mathrm{H}_{2}, \mathrm{~N}_{2}, \mathrm{O}_{2}, \mathrm{Ar}, \mathrm{Ne}, \mathrm{He}, \mathrm{Kr}\right),{ }^{3} \mathrm{He} /{ }^{4} \mathrm{He},{ }^{40} \mathrm{Ar} /{ }^{36} \mathrm{Ar}$, and several other noble-gas isotope ratios using mass spectrometry and other methods (Poreda and others, 1992). Analyses of the noble-gas subsamples are virtually free of artificial air contamination; any air in these samples is from the exhaled gas. Analytical precision is $\pm 3 \%$ for concentrations of gas species, $\pm 0.3 \%$ for ${ }^{3} \mathrm{He} /{ }^{4} \mathrm{He}$ ratios, and $\pm 0.2 \%$ for ${ }^{40} \mathrm{Ar} /{ }^{36} \mathrm{Ar}$.

A few gas condensates were collected from superheated fumaroles at Mounts Baker, Griggs, and Mageik, and from a boiling-point fumarole at Makushin. These samples were analyzed by M. Huebner and L. White for $\delta \mathrm{D}$ and $\delta^{18} \mathrm{O}$ of water. Analytical precision is \pm 1.5 per mil for $\delta \mathrm{D}$ and \pm 0.05 per mil for $\delta^{18} \mathrm{O}$.

\section{RESULTS}

After careful evaluation, we have 80 high-quality bulk-gas analyses from 1992 and 19958 together with dry-gas analyses from concomitant noble-gas and $\mathrm{C}$-isotope subsamples, 31 analyses of ${ }^{3} \mathrm{He} /{ }^{4} \mathrm{He}$ and ${ }^{40} \mathrm{Ar} /{ }^{36} \mathrm{Ar}$ from $1994-8,37$ analyses for $\delta^{13} \mathrm{C}$ of $\mathrm{CO}_{2}$ from 1994-8, and several analyses for $\delta^{13} \mathrm{C}$ of $\mathrm{CH}_{4}, \delta^{15} \mathrm{~N}$ of $\mathrm{N}_{2}$, and $\delta \mathrm{D}$ and $\delta^{18} \mathrm{O}$ of water. While broadly similar to related studies (Nehring and others, 1981; Poreda and Craig, 1989; Sheppard and others, 1992; Motyka and others, 1993), our analyses benefit from minimal sampling-induced air contamination, excellent quality assurance, and much better control on sulfur speciation. We also report the first published bulk-gas analyses from Aniakchak Crater, Mount Baker, Mount Shasta, and Trident, and the first $\mathrm{C}$ and He isotopic data for several sites.

We only present a subset of our chemical and isotopic data to support the scrubbing hypothesis. Additional isotopic data are published elsewhere (Symonds and others, 2003). Representative bulk-gas analyses for gas discharges from each volcano are reported in Table 1. Fumarole gas compositions reported as mol\% in total gas; spring gas compositions reported as mol\% in dry gas. Gases from boiling-point and superheated fumaroles are generally dominated by $\mathrm{H}_{2} \mathrm{O}, \mathrm{CO}_{2}$, and $\mathrm{H}_{2} \mathrm{~S}$, but also contain lesser but variable amounts of $\mathrm{N}_{2}, \mathrm{CH}_{4}, \mathrm{H}_{2}, \mathrm{HCl}, \mathrm{HF}$, $\mathrm{NH}_{3}, \mathrm{Ar}, \mathrm{O}_{2}$, and He. Dry-gas analyses of $\mathrm{C}$-isotope subsamples collected at all sites demonstrate that $\mathrm{H}_{2} \mathrm{~S}$ is the dominant sulfur gas species and that $\mathrm{SO}_{2}$ is below the $500 \mathrm{ppm}$ detection limit (Symonds and Evans, unpublished results). In contrast, analyses of 1998 fumarole samples from Mount St. Helens (not shown) only contain detectable amounts of $\mathrm{H}_{2} \mathrm{O}$, $\mathrm{CO}_{2}$, and air. Likewise, $\mathrm{CO}_{2}$ and meteoric components $\left(\mathrm{N}_{2}, \mathrm{O}_{2}\right.$, Ar; mostly from air-saturated water) dominate samples from springs at Akutan, Aniakchak Crater, and Mount Rainier.

Table 1 also reports the ${ }^{3} \mathrm{He} /{ }^{4} \mathrm{He}$ isotope ratios and $\delta^{13} \mathrm{C}$ of $\mathrm{CO}_{2}$ values for the noble-gas and $\mathrm{C}$-isotope subsamples, respectively, collected at the same time as the reported bulk-gas subsamples. All ${ }^{3} \mathrm{He} /{ }^{4} \mathrm{He}$ ratios are reported as $\mathrm{R}_{\mathrm{C}} / \mathrm{R}_{\mathrm{A}}$ values where $\mathrm{R}_{\mathrm{C}}$ is the ratio in the subsample, after correction for atmospheric contamination (Poreda and Craig, 1989), and $R_{A}$ is the atmospheric ratio, using air helium as the absolute standard. The $\delta^{13} \mathrm{C}$ of $\mathrm{CO}_{2}$ data are reported as per mil values (\%o) relative to PDB. 


\section{DISCUSSION}

Evidence for scrubbing

Our samples of $25^{\circ}$ to $173^{\circ} \mathrm{C} \mathrm{CRAA}$ discharges differ significantly from HTMG. First, they are dominated by meteoric rather than magmatic water, as shown by a plot of $\delta^{18} \mathrm{O}$ and $\delta \mathrm{D}$ values for condensed water from several CRAA superheated and boiling-point fumaroles (Figure 2). The isotopic shifts are in the general direction of andesitic (e.g., magmatic) water (Giggenbach, 1992), and suggest that superheated vents at Mount Mageik, for example, could contain up to $\sim 35 \%$ andesitic water. However, some of the shift in $\delta^{18} \mathrm{O}$ is probably due to hydrothermal water-rock exchange, as is likely the case for the boiling-point fumaroles on Mount Griggs. An additional complication is that all the condensates probably represent steam that separated from waters that are more isotopically enriched in $\delta^{18} \mathrm{O}$ and possibly $\delta \mathrm{D}$. So a precise computation of the amount of andesitic water in each feature cannot be made. Nonetheless, the data suggest that boiling-point vents contain mostly meteoric water and even superheated vents, which are meteoric-andesitic water mixtures, contain at least $\sim 65 \%$ meteoric water.

Second, the CRAA gases have much more water relative to anhydrous species than do HTMG. Third, they lack detectable $\mathrm{SO}_{2}$, the third most abundant species in HTMG. Fourth, they possess mixtures of meteoric and magmatic $\mathrm{Ar} .{ }^{40} \mathrm{Ar} /{ }^{36} \mathrm{Ar}$ values for most studied sites are $<350$ indicating a strong meteoric Ar component $\left({ }^{40} \mathrm{Ar} /{ }^{36} \mathrm{Ar}=295.5\right.$ for air and air-saturated water); ${ }^{40} \mathrm{Ar} /{ }^{36} \mathrm{Ar}$ values between 350 and 550 for some or all samples from Trident, Mount Baker, Mount Hood, Mount Griggs, and Mount Shasta indicate a radiogenic Ar component in these gases from magmatic or crustal sources (Symonds and others, 2003).

Fifth, in contrast to HTMG, the CRAA gases have larger amounts of $\mathrm{N}_{2}, \mathrm{CH}_{4}$, and $\mathrm{NH}_{3}$. $\mathrm{N}_{2}$ is a relatively minor species in air-free HTMG (Symonds and others, 1994; Giggenbach, 1996), but more abundant in the CRAA gases. $\mathrm{N}_{2} / \mathrm{Ar}$ ratios in our leak-resistant noble-gas subsamples are between values for air-saturated water (38.4) and air (83.6) at Augustine Volcano, Aniakchak Crater, Mount St. Helens, and Mount Rainier indicating meteoric sources of $\mathrm{N}_{2}$ at these sites (Symonds and others, 2003). Elevated $\mathrm{N}_{2} / \mathrm{Ar}$ ratios between 117 (Makushin) and 1350 (Mount Shasta) point to excess $\mathrm{N}_{2}$ at the other sites (Symonds and others, 2003); preliminary $\delta^{15} \mathrm{~N}$ values between $+1 \%$ and $+5 \%$ (relative to air) suggest a sedimentary source for the excess $\mathrm{N}_{2}$ (Symonds and others, 2003). We think this sedimentary $\mathrm{N}_{2}$ comes from thermogenic breakdown of subvolcanic sedimentary rocks (Symonds and others, 2003) in contrast to most studies that favor subducted sedimentary material as the source of sedimentary $\mathrm{N}_{2}$ in convergent-plate volcanic gases (e.g., Matsuo and others, 1978). $\mathrm{CH}_{4}$ and $\mathrm{NH}_{3}$ are trivial species in HTMG (Symonds and others, 1994; Giggenbach, 1996), but are common in hydrothermal gases where they generally come from reactions between subvolcanic hydrothermal fluids and sedimentary rocks. A sedimentary origin for $\mathrm{CH}_{4}$ is supported by the $\delta^{13} \mathrm{C}$ of $\mathrm{CH}_{4}$ data for Mount Shasta (-28\%o to $-29 \%$ orelative to PDB), Trident (-30\%o), and Akutan (-40\%o), which are much lighter than the $-15 \%$ o to $-20 \%$ o range for mantle $\mathrm{CH}_{4}$ (Welhan, 1981), although somewhat heavier $\delta^{13} \mathrm{C}_{\text {of }} \mathrm{CH}_{4}$ values for Mount Baker (-22\%o to $-23 \%$ ) may indicate mixing of magmatic and sedimentary $\mathrm{C}$ in $\mathrm{CH}_{4}$ at this site (Symonds and others, 2003).

Despite their dissimilarities with HTMG, the CRAA gases have significant magmatic components of $\mathrm{He}, \mathrm{CO}_{2}$, and $\mathrm{S}$. The ${ }^{3} \mathrm{He} /{ }^{4} \mathrm{He}$ ratios of the CRAA gases range from 2.76 to 8.11 $R_{C} / R_{A}$, but exceed $7 R_{C} / R_{A}$ at eight volcanoes (Table 1 ). Convergent-plate mantle He is $8 \pm 1$ $\mathrm{R} / \mathrm{R}_{\mathrm{A}}$ and crustal He is $0.02 \mathrm{R} / \mathrm{R}_{\mathrm{A}}$ (Poreda and Craig, 1989). Using a simple mixing model 
between mantle and crustal He, all of the CRAA discharges, including the cold springs, contain $\geq 91 \%$ mantle or magmatic He, except for summit sites venting degassed magma (Mount Shasta, $74 \%$ mantle He; Augustine Volcano, 54\% mantle He), or flank vents several $\mathrm{km}$ from the central conduit (Makushin, 60\% mantle He; Mount Rainier, 35\% mantle $\mathrm{He}$ ). The $\delta^{13} \mathrm{C}$ of $\mathrm{CO}_{2}$ data for the CRAA gases range from $-5.43 \%$ o to $-12.95 \%$ (Table 1 ), extending from typical mantle (e.g., magmatic) values of $-5 \%$ o to $-8 \%$ (Allard, 1983) towards organic carbon, generally $<-20 \%$. These results suggest that $\mathrm{CO}_{2}$ comes from a mixture of mantle (e.g., magmatic) and organic sedimentary sources. At time of writing, we have $\delta^{34} \mathrm{~S}$ of total $\mathrm{S}$ for the 1996 bulk-gas samples from Mount Hood (+4.7\%o to $+5.3 \%$ relative to CDT), Mount Shasta $(+3.8 \%$ ), Makushin $(+1.0 \%$ o to $+1.1 \%$ ) , Akutan (-0.1\%o to $-4.7 \%$ ) , and Mount Baker (-7.3\%o to $-9.8 \%$ o) (Symonds and Janik, unpublished results). The $\delta^{34} \mathrm{~S}$ values are within the reported range of volcanic sulfur gases and consistent with magmatic sulfur gases modified by scrubbing; the overall range in $\delta^{34} \mathrm{~S}$ values from $+5.3 \%$ o to $-9.8 \%$ o may reflect differences in the $\mathrm{SO}_{2} / \mathrm{H}_{2} \mathrm{~S}$ ratio in the magmatic gas and variable influence from several scrubbing reactions, especially hydrolysis of $\mathrm{SO}_{2}$ to form $\mathrm{SO}_{4}{ }^{2-}$ or $\mathrm{HSO}_{4}{ }^{2-}$ (Rollison, 1993; Ohmoto and Rye, 1979).

The above observations suggest that the CRAA discharges are chiefly scrubbed HTMG based on the following evidence: (i) The fumarolic gases (Table 1) are mostly mixtures of meteoric and andesitic water with minor amounts of magmatic-organic $\mathrm{C}$ and magmatic $\mathrm{S}$ discharged primarily as $\mathrm{CO}_{2}$ and $\mathrm{H}_{2} \mathrm{~S}$, generally consistent with predictions for the reaction between HTMG and large but variable amounts of meteoric water (Symonds and others, 2001). The $\mathrm{CO}_{2}$-rich cold-spring discharges in Table 1 probably represent HTMG scrubbed at very low gas/water ratios in concert with water-rock reaction. (ii) Vent temperatures between $80^{\circ}$ and $173^{\circ} \mathrm{C}$ (Table 1) are evidence for significant subvolcanic heat sources at all studied sites except Aniakchak Crater and Mount Rainier (Longmire Springs), but Rainier also has summit fumaroles up to $81^{\circ} \mathrm{C}$ indicating a heat source (Frank, 1995). Heat flow studies of the thermal areas at one site, Mount Hood, suggest that the heat source is deep-seated (Friedman and others, 1982). (iii) An empirical gas geothermometer (D'Amore and Panichi, 1980) applied to bulk-gas analyses from Akutan, Makushin, Mount Baker, Mount Griggs, Mount Hood, Mount Mageik, Mount Shasta, and Trident yields hydrothermal reservoir temperatures between $150^{\circ}$ and $350^{\circ} \mathrm{C}$ (Figure 3). If these hydrothermal systems are heated by magma, such temperatures suggest that magma exists at depths of 3-10 km. (iv) The CRAA discharges contain significant magmatic components of $\mathrm{He}$ and $\mathrm{CO}_{2}$.

Nature of scrubbing

Scrubbing apparently occurs at both shallow and deep levels in CRAA volcanoes. The distribution of CRAA gases on a ternary diagram of $\mathrm{CO}_{2}$, total $\mathrm{S}$, and $\mathrm{HCl}$ provides evidence for shallow scrubbing (Figure 4). The CRAA gases extend in an L-shaped pattern from the $\mathrm{CO}_{2}$ apex of the diagram towards the $\mathrm{HCl}$ apex where $\mathrm{HTMG}$ plot. This trend is consistent with the predicted results (Symonds and others, 2001) for scrubbing of HTMG by various amounts of water (Figure 4). Samples from cold soda springs at Aniakchak and Mount Rainier, and the hot soda spring at Akutan are affected most by scrubbing and imply scrubbing conditions that include very low gas/water ratios with simultaneous water-rock reaction. These are followed consecutively by samples from the hot acidic pool at Mount Shasta and boiling-point fumaroles at Mount Griggs, Akutan, Makushin, Trident, and Mount Hood; these low-temperature samples are consistent with scrubbing at $0.1 \mathrm{MPa}$ and gas/water weight ratios from 0.008 to 0.2 . In 
contrast, samples from superheated vents from Mounts Baker, Griggs, and Mageik show progressively less impact from scrubbing; these hotter samples imply scrubbing conditions ranging from 0.1 MPa and gas/water ratios of 0.04 (Mount Baker) to 1-2 $\mathrm{MPa}$ and gas water ratios of up to 1.5 (Mount Mageik).

Scrubbing conditions vary significantly from vent to vent at many CRAA volcanoes (Figure 4). As pointed out above, there are obvious variations in scrubbing conditions between springs and boiling-point fumaroles at Akutan, and boiling-point and superheated fumaroles at Mount Griggs. In addition, samples from different boiling-point fumaroles at Akutan and Mount Hood exhibit a range of $\mathrm{S} / \mathrm{CO}_{2}$ ratios, probably indicating variable degrees of scrubbing by shallow meteoric water; the sample with the high $\mathrm{S} / \mathrm{CO}_{2}$ ratio from Mount Hood may also contain extra sulfur from volatilization of near-vent sulfur deposits. Samples from different superheated fumaroles at Mounts Baker, Griggs, and Mageik also show wide variation in $\mathrm{CO}_{2}-\mathrm{S}$ $\mathrm{HCl}$ composition that may reflect variable degrees of scrubbing by shallow meteoric water. Interestingly, at Mount Mageik, as vent temperature increases from $101.6^{\circ} \mathrm{C}$ (one data point) to $130.1^{\circ} \mathrm{C}$ (one data point) to $149.8^{\circ} \mathrm{C}$ (one data point) to $167^{\circ}-173^{\circ} \mathrm{C}$ (cluster of data), the implied gas/water ratio also shows stepwise increases with an overall gain from $\sim 0.3$ to $\sim 1.5$. At the same time, the implied reservoir temperatures for all Mageik samples form a tight cluster between $301^{\circ}$ and $316^{\circ} \mathrm{C}$ (Figure 3 ). These results imply that a similar reservoir gas feeds all the Mageik fumaroles and that variable amounts of scrubbing by shallow groundwater modify the deep gas to produce the observed variations in $\mathrm{HCl}$ concentrations (Figure 4) and vent temperatures.

Similar L-shaped patterns to those in Figure 4 have been documented for gases from White Island, Ngauruhoe, Nevado del Ruiz, and Galeras (Giggenbach, 1996; Giggenbach and others, 1990; Fischer and others, 1996; Fischer and others, 1997). However, these studies generally distinguish between magmatic gases $(\mathrm{C} / \mathrm{S}<10, \mathrm{~S} / \mathrm{Cl}<100)$ and hydrothermal gases $(\mathrm{C} / \mathrm{S}>10, \mathrm{~S} / \mathrm{Cl}>100)$ in the lower and upper arms of the "L", respectively, as though they come from separate reservoirs, and chemical variation along the " $\mathrm{L}$ " is attributed to absorption of $\mathrm{HCl}$ into hydrothermal waters and mixing of magmatic and hydrothermal gases. In contrast, the scrubbing hypothesis accounts for the entire range of magmatic and hydrothermal gases as part of the continuum of reaction products between HTMG and water in a single magmatichydrothermal system.

The CRAA gases also exhibit signatures of scrubbing within deeper hydrothermal systems. Gas geothermometry (Figure 3) implies higher temperatures than those obtained during low-pressure scrubbing. Also, many CRAA volcanoes have superheated fumaroles (Makushin, Mount Mageik, Mount Baker, Mount Griggs), flank hot springs (Akutan, Makushin, Mount Baker, Mount St. Helens), or summit crater lakes that are hot and acidic (Mount Mageik), which are common surface manifestations of subvolcanic hydrothermal systems; summit or flank boiling-point fumaroles indicate either subvolcanic hydrothermal systems or HTMG interacting with near-surface water. Finally, significant amounts of $\mathrm{CH}_{4}$ and $\mathrm{NH}_{3}$ in most CRAA gases (Table 1) point to hydrothermal fluids reacting with subvolcanic sedimentary rocks (see above). Therefore, we envision a several-stage process whereby magmatic gases are scrubbed in deeper hydrothermal systems (primary scrubbing) that boil to give rise to hydrothermal gases that often undergo additional though incomplete (disequilibrium) scrubbing as the gases react with nearsurface meteoric water (secondary scrubbing). 
Conceptual model for origin of CRAA discharges

Many processes affect the compositions of gas discharges from CRAA volcanoes during their current state of repose (Figure 5). Degassing magma is the ultimate source of many species in the CRAA gases. Depths to magma are probably within 3 to $10 \mathrm{~km}$ of the summits of CRAA volcanoes based on three factors: (i) Seismic and petrologic constraints on several CRAA volcanoes (Pallister and others, 1992; Power and others, 1994; Power and others, 1995). (ii) We estimate the depths of the CRAA hydrothermal systems at $\leq 3 \mathrm{~km}$ (Figure 3). Given these shallow depths and the $>300^{\circ} \mathrm{C}$ gas-geothermometry temperatures at Mount Mageik, Makushin, Trident, and Mount Hood (Figure 3), this implies magma at 3-5 km depth for these systems. (iii) The ${ }^{3} \mathrm{He} /{ }^{4} \mathrm{He}$ isotope ratios of $>7.2 \mathrm{R}_{\mathrm{C}} / \mathrm{R}_{\mathrm{A}}$ values at Akutan, Mount Mageik, Mount Hood, Mount Baker, Trident, Mount Griggs, and Aniakchak Crater imply proximal magma.

This shallow magma degasses HTMG $\left(\mathrm{H}_{2} \mathrm{O}, \mathrm{CO}_{2}, \mathrm{SO}_{2}, \mathrm{H}_{2}, \mathrm{H}_{2} \mathrm{~S}, \mathrm{HCl}, \mathrm{HF}, \mathrm{CO}, \mathrm{Ar}, \mathrm{He}\right)$ (Symonds and others, 1994; Giggenbach, 1996) that are scrubbed by descending meteoric waters in a hydrothermal system to typically produce gases with $\geq 98 \% \mathrm{H}_{2} \mathrm{O}, \leq 2 \% \mathrm{CO}_{2}$ and $\mathrm{H}_{2} \mathrm{~S}$, and trace amounts of $\mathrm{H}_{2}, \mathrm{HCl}, \mathrm{HF}, \mathrm{Ar}$, and $\mathrm{He}$. This is the zone of primary scrubbing. Other potentially significant sources for some minor species include anoxic meteoric water as another source of Ar and crustal sedimentary rocks reacting with hydrothermal fluids to produce $\mathrm{N}_{2}$, $\mathrm{CH}_{4}$, and $\mathrm{NH}_{3}$. The resulting gas mixture may be scrubbed again (secondary scrubbing) in the zone of saturation prior to discharge from boiling-point to superheated fumaroles in CRAA volcanoes. Secondary scrubbing may be somewhat variable producing vent-to-vent variations in $\mathrm{S} / \mathrm{CO}_{2}$ ratios and $\mathrm{HCl}$ concentrations. A significant amount of the magmatic $\mathrm{S}, \mathrm{Cl}$, and $\mathrm{F}$ dissolve in hydrothermal or meteoric water, and magmatic $\mathrm{S}$ also precipitates as native sulfur. Additional sulfur loss comes from reaction of the hydrothermal fluids with the surrounding wall rocks and precipitation of sulfides and sulfates. These hydrothermal water-rock reactions weaken the edifice by altering competent volcanic rock. A significant portion of the hydrothermal fluid may discharge through the groundwater system. Neutral groundwaters may dissolve $\mathrm{CO}_{2}$ and other gases at higher pressures within the edifice and discharge them when the waters surface at springs.

Potential precursors

In addition to seismic and geodetic monitoring, gas studies can play an important role in assessing volcanic activity at CRAA volcanoes. Prior to future eruptions at CRAA volcanoes, we expect intrusion of new magma or movement of older magma to shallower levels. What gas geochemical precursors might best indicate such changes? We think that airborne monitoring of $\mathrm{CO}_{2}$ and $\mathrm{SO}_{2}$ emission rates and continuous monitoring of $\mathrm{CO}_{2}$ concentrations in soil are the best gas-monitoring methods available at time of writing. The strong evidence for scrubbing at multiple CRAA volcanoes bolsters the proposal (Symonds and others, 2001) of simultaneously monitoring the emission rates of $\mathrm{CO}_{2}$ and $\mathrm{SO}_{2}$ to help forecast future eruptions at these wet volcanoes. Movement of magma from a deep reservoir to shallow levels within the edifice would most certainly be accompanied by increased degassing. $\mathrm{CO}_{2}$ is the most likely candidate for early detection in CRAA volcanoes where scrubbing might be widespread, whereas the onset of $\mathrm{SO}_{2}$ emissions requires establishing dry magma-to-atmosphere pathways (Doukas and Gerlach, 1995; Symonds and others, 2001). The most practical methods for determining $\mathrm{CO}_{2}$ and $\mathrm{SO}_{2}$ emission rates in the snow- and ice-clad CRAA volcanoes are airborne LICOR and 
Correlation Spectroscopy, respectively (Gerlach and others, 1997). Continuous monitoring of $\mathrm{CO}_{2}$ concentrations in soils in relatively snow-poor thermal areas might also be effective (McGee and others, 2000).

However, gas sampling can augment other monitoring methods by providing complete chemical and isotopic compositional information on the gas discharges. For gas sampling, the most promising precursors might indicate the evolution of these hydrothermal discharges towards HTMG. If this evolution occurs, we expect the following precursors using predictions from thermochemical modeling (Symonds and others, 2001) and results from other volcanoes (Giggenbach, 1996; Giggenbach and others, 1990; Fischer and others, 1996; Fischer and others, 1997). Initially, as fumarolic pathways begin to dry out, we expect the gases to have increasing proportions of $\mathrm{HCl}$ relative to $\mathrm{CO}_{2}$ and total $\mathrm{S}$ as they become more magmatic, following the predicted trends in Figure 4. If pathway drying proceeds further so that HTMG vents to the surface, then we also expect significant increases in vent temperatures and concentrations of $\mathrm{SO}_{2}$ and $\mathrm{HCl}$. $\mathrm{CO}_{2}$ concentrations and several gas ratios might also increase as pathways dry out, but such changes require a case-by-case interpretation (Symonds and others, 2001).

Complete drying of fumarolic pathways seems most promising for superheated vents at Mounts Mageik, Griggs, and possibly Baker, which show the least influence from scrubbing. However, most CRAA volcanoes discharge highly scrubbed gases from boiling-point fumaroles and bubbling springs; these vents might not dry out sufficiently to show significant chemical or temperature gas precursors before the next eruption. For example, large amounts of water from snowmelt or groundwater prevented drying of magma-to-atmosphere pathways before recent eruptions at Mount St. Helens (1980) and Crater Peak of Mount Spurr (1992) (Doukas and Gerlach, 1995; Symonds and others, 2001).

Another promising precursor at some CRAA volcanoes might be increases in gas geothermometry temperatures. Intrusion of new magma or movement of older magma to shallower levels might heat a hydrothermal system. Gas geothermometry (e.g., D'Amore and Panichi, 1980) might be able to detect such heating. For instance, increases in gas geothermometer temperatures accompanied seismic unrest at Campi Flegrei in 1994 (Tedesco and Scarsi, 1999). Precursory increases in gas geothermometer temperatures seem most promising for fumaroles that show consistent geothermometer results such as at selected fumaroles at Mount Mageik, Trident, Mount Baker, and Mount Shasta (Figure 3). In addition, fumaroles that vent deeper hydrothermal systems (e.g., Trident, Mount Mageik; Figure 3) might show earlier increases in geothermometer temperatures than fumaroles that vent shallow systems (e.g., Mount Baker, Mount Shasta; Figure 3).

Isotopic changes in the discharge gases may also precede eruptions at some CRAA volcanoes. In particular, future unrest at CRAA volcanoes may produce changes in $\delta^{13} \mathrm{C}_{\text {of }} \mathrm{CO}_{2}$ if the activity modifies the proportions of mantle and organic sedimentary $\mathrm{C}$ implied in Table 1; such change might occur along with magma movement. In addition, magma intrusion or seismic unrest is often accompanied by increases in ${ }^{3} \mathrm{He} /{ }^{4} \mathrm{He}$ (Tedesco and Scarsi, 1999; Sorey and others, 1993). However, significant increases in ${ }^{3} \mathrm{He} /{ }^{4} \mathrm{He}$ appear unlikely at many CRAA volcanoes because they already discharge near-magmatic He (Table 1). But the lower values of 5.90 and $4.28 \mathrm{R}_{\mathrm{C}} / \mathrm{R}_{\mathrm{A}}$ at summit fumaroles on Mount Shasta and Augustine Volcano, respectively, suggest that these magmatic systems are relatively degassed and that intrusion of new magma prior to the next eruptions at these volcanoes might produce precursory increases in ${ }^{3} \mathrm{He} /{ }^{4} \mathrm{He}$. Indeed, between the 1976 and 1986 eruptions of Augustine Volcano, values of $R_{C} / R_{A}$ were 7.66 (1978) and 7.60 (1982) (Poreda and Craig, 1989). Increases in ${ }^{3} \mathrm{He} /{ }^{4} \mathrm{He}$ are also potential 
precursors at flank vents at Mount Rainier (Longmire Springs) and Makushin, which currently have $R_{C} / R_{A}$ values of 2.76 and 4.81. In addition, intrusion of new magma at Mount Rainier might produce significant increases in He concentrations in the Longmire gases since the leakresistant noble-gas subsamples from Longmire only contain 30 to $50 \mathrm{ppb} \mathrm{He}$.

Hazards implications

By producing acidic fluids, scrubbing contributes to ongoing and potentially hazardous hydrothermal alteration at CRAA volcanoes. Acidic fluids dissolve and alter competent volcanic rock, processes that may influence edifice stability by forming zones of weakness along fractures, dikes, and bedding surfaces (López and Williams, 1993; Scott and others, 1995; Crowley and Zimbelman, 1997). Clay-size minerals in hydrothermal alteration can also contribute to the formation of debris flows that can travel farther as a cohesive unit than more granular flows (Scott and others, 1995 ).

To determine the impact of ongoing scrubbing on rock-alteration hazards at CRAA volcanoes, we need estimates of the scrubbing rates. Mount Baker is an example where we can estimate scrubbing rates using $\mathrm{CO}_{2}$ emission rates and bulk-gas compositions. In July 1998 Mount Baker was emitting $2.0-2.5 \times 10^{5} \mathrm{~kg} /$ day of $\mathrm{CO}_{2}$ (M. P. Doukas and T. M. Gerlach, personal communication, 1999). Similar $\mathrm{CO}_{2}$ emission rates of $1.87 \pm 0.26 \times 10^{5} \mathrm{~kg} /$ day were measured in September 2000 (McGee and others, 2001). Using the $1998 \mathrm{CO}_{2}$ emission rate and the $\mathrm{H}_{2} \mathrm{~S} / \mathrm{CO}_{2}$ and $\mathrm{HCl} / \mathrm{CO}_{2}$ ratios from August 1997 gas samples (Symonds, Counce, and Janik, unpublished data), we estimate discharge rates of only $7.1-15 \times 10^{3} \mathrm{~kg} /$ day for $\mathrm{H}_{2} \mathrm{~S}$ and $10-65$ $\mathrm{kg} /$ day for $\mathrm{HCl}$. The molar $\mathrm{C} / \mathrm{S}(13-22)$ and $\mathrm{C} / \mathrm{Cl}(3200-17000)$ ratios in the discharged gases are substantially higher than in typical andesitic-dacitic convergent-plate HTMG (Symonds and others, 1994), implying that the Mount Baker hydrothermal system scrubs $1.0-8.4$ x $10^{4} \mathrm{~kg} / \mathrm{day}$ of $\mathrm{S}$ and $1.1-6.7 \times 10^{4} \mathrm{~kg} /$ day of $\mathrm{Cl}$. In addition, several Aleutian-Arc volcanoes probably have high scrubbing rates based on visual degassing rates, although $\mathrm{CO}_{2}$ emission rates have not yet been measured at these sites. Mount Mageik is by far the most vigorously degassing volcano in our study and it clearly has high rates of scrubbing. But Mount Griggs, Trident, Akutan, and Makushin also display significant amounts of degassing and therefore probably have notable rates of scrubbing. However, we think it likely that Mounts Shasta and Hood have low scrubbing rates because these volcanoes have very low $\mathrm{CO}_{2}$ emission rates compared to Mount Baker (M. P. Doukas and T. M. Gerlach, personal communication, 1999). Nonetheless, we cannot preclude the possibility that Mount Shasta, Mount Hood, and other CRAA volcanoes have high scrubbing rates even without significant $\mathrm{CO}_{2}$ degassing or surficial evidence of degassing; it is possible that scrubbing is so severe that it even prevents significant $\mathrm{CO}_{2}$ emissions.

We expect that most of the ongoing alteration in CRAA volcanoes is associated with primary scrubbing in hydrothermal systems. Using the predicted depths to the tops of the hydrothermal systems for 8 CRAA volcanoes (Figure 3), we infer that alteration is occurring high within the edifices of Mounts Shasta, Griggs, and Baker, but near or below the base of the edifices of Mount Mageik, Makushin, Trident, and Mount Hood; at Akutan, alteration occurs both at the summit and the base. Secondary scrubbing can also produce shallow alteration when acidic gases boiled from these hydrothermal systems are scrubbed by groundwater. Such secondary alteration may be most effective for the deep but hot hydrothermal systems at Mount Hood, Trident, Makushin, and Mount Mageik since high-pressure boiling hydrothermal systems 
release gases that are richer in $\mathrm{H}_{2} \mathrm{~S}$ and $\mathrm{HCl}$ than gases from low-pressure boiling systems (Symonds and others, 2001). Secondary scrubbing is also more effective at boiling-point fumaroles than at superheated fumaroles where more of the acidic gases vent into the atmosphere. For instance, the boiling-point fumarole fields at Makushin and Trident display extensive advanced argillic alteration. Generation of alteration from secondary scrubbing also seems promising for Mount Mageik where some of the hydrothermal gases are scrubbed by an acidic summit-crater lake that may drain into and alter the edifice.

Ultimately, the potential hazards associated with hydrothermal alteration at each CRAA volcano depends on the spatial distribution of hydrothermal alteration and the proximity of the volcano to civilization. Mount Rainier is an example of a CRAA volcano that is both close to Washington's crowded Puget Sound region and also displays extensive hydrothermal alteration that may contribute to edifice instability and the generation of cohesive debris flows (Scott and others, 1995; Crowley and Zimbelman, 1997). Recently, high-resolution airborne magnetic and electromagnetic surveys have been used to map the volume and extent of hydrothermal alteration at Mount Rainier (Finn and others, 2001). These maps help constrain modeling of the role of hydrothermal alteration in potential edifice failures at Mount Rainier (Reid and others, 2001). Based on our work, we recommend additional geophysical surveys and edifice-stability modeling at Mount Baker where there is evidence of substantial ongoing shallow alteration within the upper edifice. Mount Baker displays extensive upper-edifice alteration, and has produced several Holocene debris flows that contain significant amounts of the alteration minerals, kaolinite and alunite (Frank, 1983). Mount Baker is also close enough to civilization that debris flows or edifice failure could be hazardous (Gardner and others, 1995). Another potential target is the upper edifice of Mount Mageik, which shows evidence of substantial ongoing alteration, although Mageik is too remote to have significant debris-flow or edificefailure hazards. Though close to civilization, the south side of Mount Hood and the summit region of Mount Shasta appear less promising because surficial alteration is not particularly extensive at these sites and, as discussed above, scrubbing rates appear relatively low.

Finally, hydrothermal systems themselves can be hazardous. Precipitation of silica and minerals can cause self sealing of hydrothermal systems, producing rapid increases in pressure that sometime lead to hydrothermal eruptions (e.g., the 1843 eruption of Mount Baker). Intrusions or heating of deeper hydrothermal systems also generates rapid excursions in pressure that might help trigger deep-seated edifice collapse.

\section{CONCLUSIONS}

While most potentially restless CRAA volcanoes have not erupted for decades to centuries, many degas small to moderate amounts of HTMG from 3-10 km deep magma reservoirs. The magma reservoirs are apparently at least partially resupplied during repose-otherwise, how can one account for near-mantle ${ }^{3} \mathrm{He} /{ }^{4} \mathrm{He}$ values at CRAA volcanoes without recent magmatic eruptions (e.g., Mounts Baker and Griggs)? Prior to discharge from $\leq 173^{\circ} \mathrm{C}$ fumaroles and springs, the HTMG are heavily modified from variable amounts of scrubbing by deep hydrothermal and shallow meteoric water. The concept of scrubbing enables one to view these hydrothermal gases as part of the continuum of reaction products between HTMG and water.

By masking magmatic degassing, scrubbing presents a challenge for gas-monitoring of CRAA volcanoes. We concur with other recent studies (Doukas and Gerlach, 1995; McGee and 
others, 2000; Symonds and others, 2001) that the best strategies for detecting gas precursors to future CRAA eruptions are to measure periodically the emission rates of $\mathrm{CO}_{2}$ and $\mathrm{SO}_{2}$, and to monitor continuously $\mathrm{CO}_{2}$ concentrations in soils around volcanic vents. $\mathrm{CO}_{2}$ is the second-most abundant species in magmatic gases and has a relatively low solubility in water and magma; hence, it is an ideal candidate for monitoring magma movement. In contrast, $\mathrm{SO}_{2}$ - third in abundance behind $\mathrm{CO}_{2}$ - has a relatively high solubility in water making it an ideal candidate to detect drying out of degassing pathways. Timely sampling of fumaroles can augment the geochemical surveillance program by providing complete chemical and isotopic compositions of the gas discharges. In particular, the extent of scrubbing can be determined by measuring the relative proportions of $\mathrm{CO}_{2}$ to total $\mathrm{S}$ to $\mathrm{HCl}$ (Figure 4), the vent temperatures, and the concentrations of $\mathrm{SO}_{2}$ and $\mathrm{HCl}$. The chemical compositions of gases can also constrain gas geothermometers to help detect changes the temperature of the hydrothermal systems; this might be particular effective for selected vents at Mount Mageik, Trident, Mount Baker, and Mount Shasta, which exhibit relatively constant geothermometry temperatures. In addition, changes in $\delta^{13} \mathrm{C}$ of $\mathrm{CO}_{2}$ might indicate magma movement, since the $\delta^{13} \mathrm{C}$ values of the CRAA gases indicate mixing between magmatic and organic sedimentary sources. Finally, intrusion of new magma might be accompanied by increases in ${ }^{3} \mathrm{He} /{ }^{4} \mathrm{He} \mathrm{R}_{\mathrm{C}} / \mathrm{R}_{\mathrm{A}}$ values at Mount Rainier (Longmire Springs), Augustine Volcano, Makushin, and Mount Shasta, since these sites currently have relatively low $R_{C} / R_{A}$ values. Precursory increases in $R_{C} / R_{A}$ values at other CRAA volcanoes seem unlikely because they already are close to the mantle value.

Through hydrolysis of $\mathrm{SO}_{2}, \mathrm{H}_{2} \mathrm{~S}$, and $\mathrm{HCl}$, scrubbing creates acidic fluids that hydrothermally alter rocks in 0.2 - to 3-km-deep hydrothermal systems and in fields of boilingpoint fumaroles near the surface at many CRAA volcanoes. Hydrothermal alteration is potentially hazardous because it may influence edifice stability and contribute to the formation of more-hazardous cohesive debris flows. There is evidence of significant rates of scrubbing and hence alteration at Mount Baker, Mount Griggs, Trident, Akutan, and Makushin. Mount Baker raises concern because the ongoing scrubbing occurs high in the edifice, it has significant amount of upper edifice alteration, it has produced several alteration-rich Holocene debris flows, and it is close enough to civilization that debris flows or edifice failure could be hazardous. Therefore, we recommend aerogeophysical and hazard-modeling studies of the volume, extent, and hazards of hydrothermal alteration at Mount Baker, similar to recent investigations of Mount Rainier (Finn and others, 2001; Reid and others, 2001). Other potential hazards associated with the CRAA volcano hydrothermal systems include hydrothermal eruptions and, for deeper systems intruded by magma, deep-seated edifice collapse.

\section{ACKNOWLEDGMENTS}

Funding for this work was provided by the U.S. Geological Survey's Volcano Hazards Program. M. Huebner and L. White provided the $\delta \mathrm{D}$ and $\delta^{18} \mathrm{O}$ analyses. We thank C. Gardner, T. Gerlach, J. Lowenstern, and W. Scott for helpful reviews and discussions.

\section{REFERENCES}

Allard, P., 1983, The origin of hydrogen, carbon, sulfur, nitrogen and rare gases in volcanic exhalations: evidence from isotope geochemistry, in Tazieff, H., and Sabroux, J.-C., eds., Forecasting Volcanic Events: Elsevier, Amsterdam, p. 337-386. 
Armannsson, H. , Gislason, G., and Hauksson, T., 1982, Magmatic gases in well fluids aid the mapping of the flow pattern in a geothermal system: Geochimica et Cosmochimica Acta, v. 46, p. 167-177.

Brimhall, G. H., and Ghiorso, M. S., 1983, Origin and ore-forming consequences of the advanced argillic alteration process in hypogene environments by magmatic gas contamination of meteoric fluids: Economic Geology, v. 78, p. 73-90.

Burham, C. W., 1979, Magmas and hydrothermal fluids, in Barnes, H. L., ed., Geochemistry of Hydrothermal Ore Deposits: 2nd edition, John Wiley, New York, p. 71-136.

Craig, H. , 1961, Isotopic variation in meteoric waters: Science, v. 133, p. 1702-1703.

Crowley, J. K., and Zimbelman, D. R., 1997, Mapping hydrothermally altered rocks on Mount Rainier, Washington, with Airborne Visible/Infrared Imaging Spectrometer (AVIRIS) data: Geology, v. 25, p. 559-562.

D’Amore, F., and Panichi, C., 1980, Evaluation of deep temperatures of hydrothermal systems by a new gas geothermometer: Geochimica et Cosmochimica Acta, v. 44, p. 549-556.

Doukas, M. P., and Gerlach, T. M., 1995, Sulfur dioxide scrubbing during the 1992 eruptions of Crater Peak, Mount Spurr Volcano, Alaska, in Keith, T. E. C., ed., The 1992 eruptions of Crater Peak Vent, Mount Spurr Volcano, Alaska: U.S. Geological Survey Bulletin 2139, p. 47-57.

Fahlquist, L., and Janik, C. J., 1992, Procedures for collecting and analyzing gas samples from geothermal systems: U.S. Geological Survey Open-File Report 92-211, 19 p.

Finn, C. A., Sisson, T. W., and Deszcz-Pan, Maryla, 2001, Aerogeophysical measurements of collapse-prone hydrothermally altered zones at Mount Rainier volcano: Nature, v. 409, p. 600-603.

Fischer, T. P., Arehart, G. B., Sturchio, N. C., and Williams, S. N., 1996, The relationship between fumarole gas composition and eruptive activity at Galeras Volcano, Colombia: Geology, v. 24, p. 531-534.

Fischer, T. P., Sturchio, N. C., Stix, J., Arehart, G. B., Counce, D., and Williams, S. N., 1997, The chemical and isotopic composition of fumarolic gases and spring discharges from Galeras Volcano, Columbia: Journal of Volcanology and Geothermal Research, v. 77, p. 229-253.

Frank, D., 1983, Origin, distribution, and rapid removal of hydrothermally formed clay at Mount Baker, Washington: U.S. Geological Survey Professional Paper 1022-E, 31 p.

Frank, D., 1995, Surficial extent and conceptual model of hydrothermal system at Mount Rainier, Washington: Journal of Volcanology and Geothermal Research, v. 65, p. 51-80.

Friedman, J. D., Williams, D. L., and Frank, D., 1982, Structural and heat flow implications of infrared anomalies at Mt. Hood, Oregon, 1972-1977: Journal of Geophysical Research, v. 87, p. 2793-2803.

Gardner, C. A., Scott, K. M., Miller, C. D., Myers, B., Hildreth, W., and Pringle, P. T., 1995, Potential volcanic hazards from future activity of Mount Baker, Washington: U.S. Geological Survey Open-File Report 95-498, 16p., 1 map sheet, scale 1:100,000.

Gerlach, T. M., Delgado, H., McGee, K. A., Doukas, M. P., Venegas, J. J., and Cárdenas, L., 1997, Application of the LI-COR $\mathrm{CO}_{2}$ analyzer to volcanic plumes; a case study, volcán Popocatépetl, Mexico, June 7 and 10, 1995: Journal of Geophysical Research, v. 102, p. 8005-8019. 
Giggenbach, W. F., 1992, Isotopic shifts in waters from geothermal and volcanic systems along convergent plate boundaries and their origin: Earth Planetary and Science Letters, v. 113, p. 495-510.

Giggenbach, W. F., 1996, Chemical composition of volcanic gases, in Scarpa, R., and Tilling, R. I., eds., Monitoring and Mitigation of Volcano Hazards: Springer-Verlag, Berlin, p. 221-256.

Giggenbach, W. F., García, P. N., Londoño, C. A.,. Rodriguez, V. L. A, Rojas, G. N., and Calvache, V. M. L., 1990, The chemistry of fumarolic vapor and thermal-spring discharges from the Nevado del Ruiz volcanic-magmatic hydrothermal system, Columbia: Journal of Volcanology and Geothermal Research, v. 42, p. 13-39.

Hedenquist, J. W., and Lowenstern, J. B., 1994, The role of magmas in the formation of hydrothermal ore deposits: Nature, v. 370, p. 519-527.

Holland, H. D., 1965, Some applications of thermochemical data to problems of ore deposits II; mineral assemblages and the composition of ore-forming fluids: Economic Geology, v. 60, p. 1101-1166.

Keith, T. E. C., Thompson, J. M., Hutchinson, R. A., and White, L. D., 1992, Geochemistry of waters in the Valley of Ten Thousand Smokes region, Alaska: Journal of Volcanology and Geothermal Research, v. 49, p. 209-231.

Le Guern, F., Gerlach, T. M., and Nohl, A., 1982, Field gas chromatograph analyses of gases from a glowing dome at Merapi volcano, Java, Indonesia, 1977, 1978, 1979: Journal of Volcanology and Geothermal Research, v. 47, p. 223-245.

López, D. L., and Williams, S. N., 1993, Catastrophic volcanic collapse; relation to hydrothermal processes: Science, v. 260, p. 1794-1796.

Matsuo, S., Suzuki, M., and Mizutani, Y., 1978, Nitrogen to argon ratios in volcanic gases, in Alexander, E. C., Jr., and Ozima, M., eds., Terrestrial Rare Gases: Center for Academic Publications Japan, Tokyo, p. 17-25.

McGee, K. A., Doukas, M. P., and Gerlach, T. M., 2001, Quiescent hydrogen sulfide and carbon dioxide degassing from Mount Baker, Washington: Geophysical Research Letters, v. 28, p. 4479-4482.

McGee, K. A., Gerlach, T. M., Kessler, R., and Doukas, M. P., 2000, Geochemical evidence for a magmatic $\mathrm{CO}_{2}$ degassing event at Mammoth Mountain, California, September-December 1997: Journal of Geophysical Research, v. 105, p. 8447-8456.

Motyka, R. J., Liss, S. A., Nye, C. J., and Moorman, M. A., 1993, Geothermal resources of the Aleutian Arc: Alaska Division of Geological and Geophysical Surveys Professional Report 114, 17 p., 3 plates.

Nehring, N. L., Wollenberg, H. A., and Johnston, D. A., 1981, Gas analyses of fumaroles from Mt. Hood, Oregon: U.S. Geological Survey Open-File Report 81-236, 9p.

Ohmoto, H., and Rye, R. O., 1979, Isotopes of sulfur and carbon, in Barnes, H. L., ed., Geochemistry of Hydrothermal Ore Deposits: 2nd edition, John Wiley \& Sons, New York, p. 509-567.

Pallister, J. S., Hobblitt, R. P., Crandell, D. R., and Mullineaux, D. R., 1992, Mount St. Helens a decade after the 1980 eruptions; magmatic models, chemical cycles, and a revised hazards assessment: Bulletin of Volcanology, v. 54, p. 126-146.

Poreda, R., and Craig, H., 1989, Helium isotope ratios in circum-Pacific volcanic arc: Nature, v. 338, p. 473-478. 
Poreda, R. J., Craig, H., Arnórsson, S., and Welhan, J. A., 1992, Helium isotopes in Icelandic geothermal systems I. ${ }^{3} \mathrm{He}$, gas chemistry, and ${ }^{13} \mathrm{C}$ relations: Geochimica et Cosmochimica Acta, v. 56, p. 4221-4228.

Power, J. A., Jolly, A. D., Page, R. A., and McNutt, S. R., 1995, Seismicity and forecasting of the 1992 eruptions of Crater Peak vent, Mount Spurr Volcano, Alaska; an overview, in Keith, T. E. C., ed., The 1992 eruptions of Crater Peak Vent, Mount Spurr Volcano, Alaska: U.S. Geological Survey Bulletin 2139, p. 149-159.

Power, J. A., Lahr, J. C., Page, R. A., Chouet, B. A., Stephens, C. D., Harlow, D. H., Murray, T. L., and Davis, J. N., 1994, Seismic evolution of the 1989-1990 eruption sequence of Redoubt Volcano, Alaska, in Miller, T. P., and Chouet, B. A., eds., The 1989-1990 eruptions of Redoubt Volcano, Alaska: Journal of Volcanology and Geothermal Research, v. 62,p. 69-94.

Reid, M. E., Sisson, T. W., and Brien, D. L., 2001, Volcano collapse promoted by hydrothermal alteration and edifice shape, Mount Rainier, Washington: Geology, v. 29, p. 779-782.

Rollison, H. , 1993, Using geochemical data: evaluation, presentation, interpretation: Wiley \& Sons, New York, 325 p.

Scott, K. M., Vallance, J. W., and Pringle, P. T., 1995, Sedimentology, behavior, and hazards of debris flows at Mount Rainier, Washington: U.S. Geological Survey Professional Paper 1547, 56 p., 1 plate.

Sheppard, D. S., Janik, C. J., and Keith, T. E. C., 1992, A comparison of gas geochemistry of fumaroles in the 1912 ashflow sheet and on active stratovolcanoes, Katmai National Park, Alaska: Journal of Volcanology and Geothermal Research, v. 53, p. 185-197.

Sheppard, S. M. F., Nielsen, R. L., and Taylor, H. P., 1969, Oxygen and hydrogen isotope ratios of clay minerals from porphyry copper deposits: Economic Geology, v. 64, p. 755-777.

Sorey, M. L., Kennedy, B. M., Evans, W. C., Farrar, C. D., and Suemnicht, G. A., 1993, Helium isotope and gas discharge variations associated with crustal unrest in Long Valley Caldera, California, 1989-1992: Journal of Geophysical Research, v. 98, p. 15871-15889.

Symonds, R. B., Gerlach, T. M., and Reed, M. H., 2001, Magmatic gas scrubbing: implications for volcano monitoring, in Allard, Patrick, Shinohara, Hiroshi, and Wallace, Paul, eds., Magma degassing through volcanoes; A tribute to Werner F. Giggenbach: Journal of Volcanology and Geothermal Research, v. 108, p. 303-341.

Symonds, R. B., Poreda, R. J., Evans, W. C., Janik, C. J., and Ritchie, B. E., 2003, Mantle and crustal sources of carbon, nitrogen, and noble gases in Cascade-Range and Aleutian-Arc volcanic gases: U.S. Geological Survey Open-File Report 03-436, 26 p.

Symonds, R. B., Rose, W. I., Bluth, G. J. S., and Gerlach, T. M., 1994, Volcanic-gas studies: methods, results, and applications, in Carrol, M. R., and Holloway, J. R., eds., Volatiles in Magmas, Reviews of Mineralogy, v. 30, p. 1-66.

Tedesco, D., and Scarsi, P., 1999, Chemical (He, $\mathrm{H}_{2}, \mathrm{CH}_{4}, \mathrm{Ar}, \mathrm{N}_{2}$ ) and isotopic (He, Ne, Ar, C) variations at the Solfatara crater (southern Italy): mixing of different sources in relation to seismic activity: Earth and Planetary Science Letters, v. 171, p. 465-480.

Trujillo, P. E., Counce, D., Grigsby, C. O., Goff, F., and Shevenell, L., 1987, Chemical analysis and sampling techniques for geothermal fluids and gases at the Fenton Hill laboratory: Los Alamos National Laboratory Report LA-11006-MS, 84 p.

Welhan, J. A., 1981, Carbon and hydrogen gases in hydrothermal systems: the search for a mantle source: PhD thesis, University of California, San Diego, 194 p. 
Table 1. Representative chemical compositions (in mol\% in total gas for fumaroles and mol\% in dry gas for springs), ${ }^{3} \mathrm{He} /{ }^{4} \mathrm{He}$ ratios (in $\mathrm{R}_{\mathrm{C}} / \mathrm{R}_{\mathrm{A}}$ values), and $\delta^{13} \mathrm{C}$ of $\mathrm{CO}_{2}$ (in \%o relative to PDB) for gases from Cascade-Range and Aleutian-Arc volcanoes

\begin{tabular}{|c|c|c|c|c|c|c|c|c|c|c|c|c|c|c|c|c|c|}
\hline Volcano & $\begin{array}{c}\begin{array}{c}\text { Sub- } \\
\text { sample }^{\mathrm{a}}\end{array} \\
\text { Co }^{2}\end{array}$ & $\begin{array}{l}\text { Vent } \\
\text { type }^{\text {b }}\end{array}$ & $\begin{array}{c}\mathrm{T} \\
\left({ }^{\circ} \mathrm{C}\right)\end{array}$ & $\mathrm{H}_{2} \mathrm{O}$ & $\mathrm{CO}_{2}$ & $\mathrm{H}_{2} \mathrm{~S}$ & $\mathrm{~N}_{2}$ & $\mathrm{CH}_{4}$ & $\mathrm{H}_{2}$ & $\mathrm{HCl}$ & $\mathrm{HF}$ & $\mathrm{NH}_{3}$ & $\mathrm{Ar}$ & $\mathrm{O}_{2}$ & $\mathrm{He}$ & $\begin{array}{c}{ }^{3} \mathrm{He} /{ }^{4} \mathrm{He} \\
\mathrm{R}_{\mathrm{C}} / \mathrm{R}_{\mathrm{A}}\end{array}$ & $\begin{array}{l}\delta^{13} \mathrm{C} \\
(\% o)\end{array}$ \\
\hline \multicolumn{18}{|c|}{ Boiling-point and Superheated Fumaroles } \\
\hline Akutan & $960729-1$ & $\mathrm{SF}$ & 96.6 & 99.212 & 0.710 & 0.0495 & 0.0250 & 0.0025 & $5.2 \times 10^{-4}$ & $5.7 \times 10^{-9}$ & $<3 \times 10^{-6}$ & $<3.1 \times 10^{-6}$ & $1.5 \times 10^{-4}$ & $1.9 \times 10^{-4}$ & $4.5 \times 10^{-6}$ & 7.24 & -12.0 \\
\hline$"$ & $960728-1$ & $\mathrm{FF}$ & 97.8 & 94.404 & 5.33 & 0.114 & 0.113 & 0.0129 & 0.0273 & $<5.3 \times 10^{-7}$ & $<4 \times 10^{-6}$ & $2.6 \times 10^{-4}$ & $3.1 \times 10^{-4}$ & $2.5 \times 10^{-4}$ & $1.9 \times 10^{-5}$ & 7.26 & -9.70 \\
\hline Augustine & $920713-2$ & $\mathrm{SF}$ & 97.0 & 99.84 & 0.0073 & 0.0046 & 0.0025 & $9.5 \times 10^{-7}$ & 0.1399 & $1 \times 10^{-4}$ & $1 \times 10^{-4}$ & ND & $\mathrm{ND}$ & $5.7 \times 10^{-4}$ & $\mathrm{BD}$ & $4.28^{\ddagger}$ & $-5.43^{\mathrm{c}}$ \\
\hline Baker & $970807-5$ & $\mathrm{SF}$ & 134.4 & 98.267 & 1.623 & 0.0916 & 0.00720 & 0.00709 & 0.00381 & $5.1 \times 10^{-4}$ & $<0.0016$ & $2 \times 10^{-5}$ & $1 \times 10^{-5}$ & $9 \times 10^{-6}$ & $1 \times 10^{-5}$ & 7.70 & -6.88 \\
\hline$"$ & $970807-8$ & $\mathrm{SF}$ & 107.7 & 98.201 & 1.655 & 0.126 & 0.00751 & 0.00746 & 0.00271 & $<1 \times 10^{-4}$ & $<0.0018$ & $1 \times 10^{-5}$ & $9 \times 10^{-6}$ & $5 \times 10^{-6}$ & $1 \times 10^{-5}$ & ND & -6.12 \\
\hline Griggs & $950722-1$ & $\mathrm{SF}$ & 93.8 & 98.878 & 1.06 & 0.0290 & 0.0288 & $<1.7 \times 10^{-5}$ & $7.9 \times 10^{-4}$ & $<0.0032$ & ND & $1.5 \times 10^{-4}$ & $4.5 \times 10^{-4}$ & $1.1 \times 10^{-4}$ & ND & 8.11 & -6.29 \\
\hline$"$ & $970718-1$ & $\mathrm{FF}$ & 99.2 & 96.741 & 2.951 & 0.252 & 0.0204 & $2.46 \times 10^{-4}$ & $9.8 \times 10^{-5}$ & 0.0341 & $<0.0017$ & $<9 \times 10^{-6}$ & $1.3 \times 10^{-4}$ & $1 \times 10^{-5}$ & $6.4 \times 10^{-5}$ & 7.94 & -5.59 \\
\hline Hood & $970508-1$ & $\mathrm{SF}$ & 90.3 & 98.495 & 1.172 & 0.260 & 0.0331 & $<7 \times 10^{-6}$ & 0.0396 & $<1 \times 10^{-4}$ & $<0.0015$ & $<9 \times 10^{-6}$ & $2.3 \times 10^{-4}$ & $6 \times 10^{-5}$ & $4 \times 10^{-5}$ & ND & ND \\
\hline$"$ & 970909-2 & $\mathrm{SF}$ & 91 & 97.650 & 2.156 & 0.115 & 0.0286 & $<8 \times 10^{-6}$ & 0.0504 & $7.8 \times 10^{-5}$ & $<0.0030$ & $<1 \times 10^{-5}$ & $2.4 \times 10^{-4}$ & $4 \times 10^{-5}$ & $2 \times 10^{-5}$ & 7.60 & -9.08 \\
\hline Mageik & $970719-5$ & $\mathrm{SF}$ & 172.9 & 96.003 & 3.485 & 0.366 & 0.0319 & 0.00103 & 0.0636 & 0.0484 & $<0.0044$ & 0.00120 & $1.1 \times 10^{-4}$ & $4 \times 10^{-5}$ & $<1 \times 10^{-5}$ & 7.57 & -6.75 \\
\hline Makushin & $960724-1$ & $\mathrm{FF}$ & 100 & 99.870 & 0.109 & 0.0110 & 0.00876 & $1.2 \times 10^{-5}$ & 0.0014 & $7.7 \times 10^{-9}$ & $<2 \times 10^{-6}$ & $2.6 \times 10^{-6}$ & $1.5 \times 10^{-4}$ & $4 \times 10^{-5}$ & $\mathrm{BD}$ & 4.81 & -7.57 \\
\hline Trident & $970717-1$ & $\mathrm{FF}$ & 94.2 & 89.15 & 8.188 & 0.346 & 0.192 & 0.231 & 1.87 & 0.0011 & 0.011 & 0.0155 & 0.002 & 0.001 & $<2 \times 10^{-4}$ & 7.82 & -10.51 \\
\hline \multicolumn{18}{|c|}{ Thermal and Cold Springs } \\
\hline Akutan & $960727-2$ & FSS & 97.4 & NA & 89.1 & $<0.004$ & 8.83 & 1.65 & 0.014 & $3.7 \times 10^{-4}$ & $<0.0002$ & $3.1 \times 10^{-4}$ & 0.37 & 0.074 & $5.3 \times 10^{-4}$ & 5.78 & -12.34 \\
\hline Rainier & $970808-5$ & FSS & 20 & NA & 99.78 & $<0.001$ & 0.144 & 0.0020 & $5.3 \times 10^{-4}$ & $<0.003$ & $<0.039$ & $<1 \times 10^{-4}$ & 0.00295 & 0.0699 & $4 \times 10^{-5}$ & 2.76 & -12.95 \\
\hline Shasta & $970626-1$ & SAP & 80.2 & NA & 94.44 & 0.279 & 2.95 & 1.00 & 0.952 & 0.0078 & 0.21 & $<3 \times 10^{-4}$ & 0.016 & 0.135 & $<5 \times 10^{-4}$ & 5.90 & -11.4 \\
\hline
\end{tabular}

NA, not applicable; ND, not determined; BD, below detection.

$\mathrm{CO}$ is below detection in all but the Augustine sample $\left(8 \times 10^{-4}\right)$.

${ }^{a}$ Represents year, month, day, and subsample sequence.

${ }^{\mathrm{b}} \mathrm{SF}$, summit fumarole; FF, flank fumarole; SSS, summit soda spring; FSS, flank soda spring; SAP, summit acid pool.

${ }^{\mathrm{c}}$ Subsample collected on $7 / 28 / 94$. 


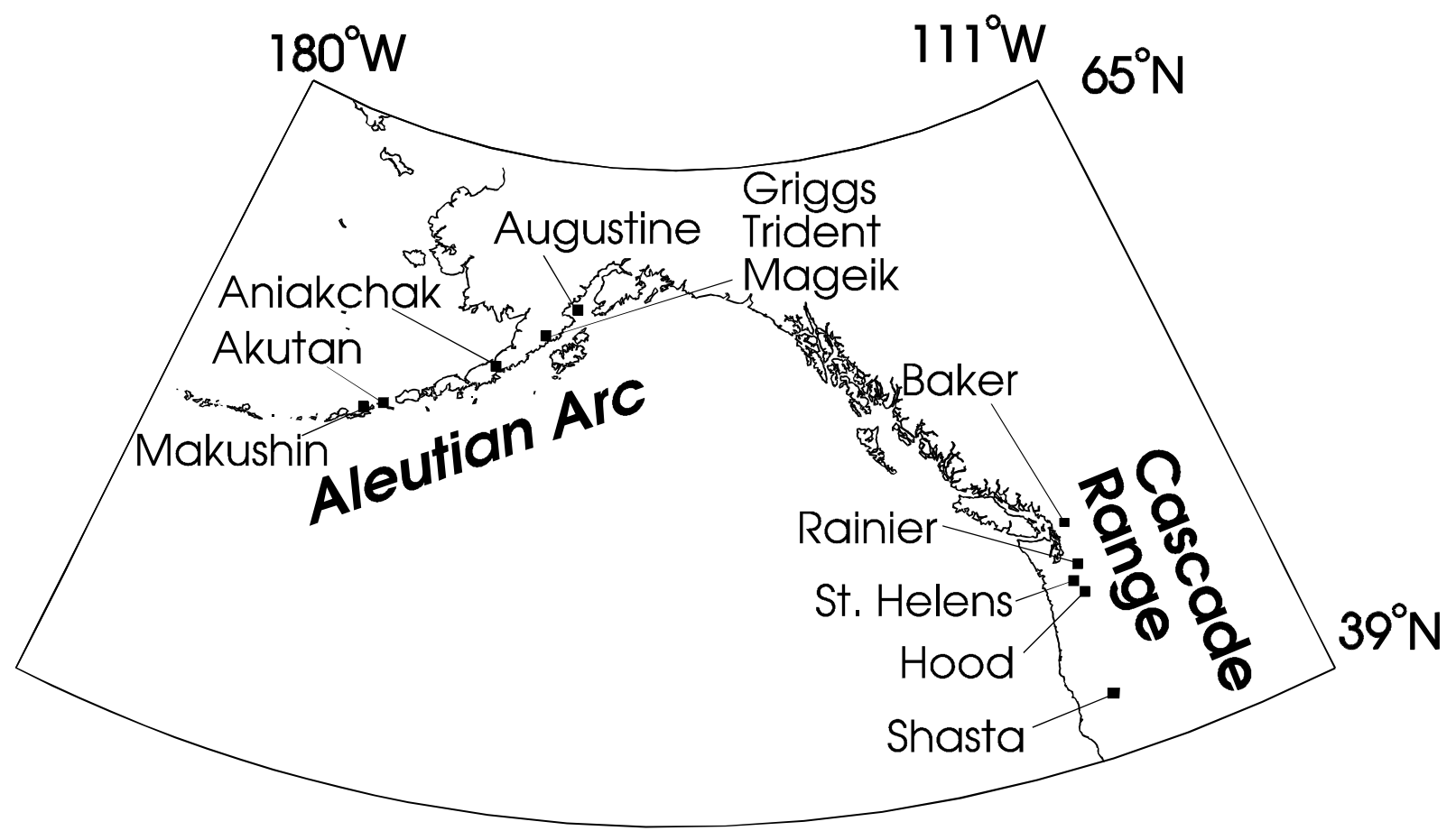

Figure 1. Map of northwestern North America showing location of volcanoes sampled in the Cascade Range and Aleutian Arc. 


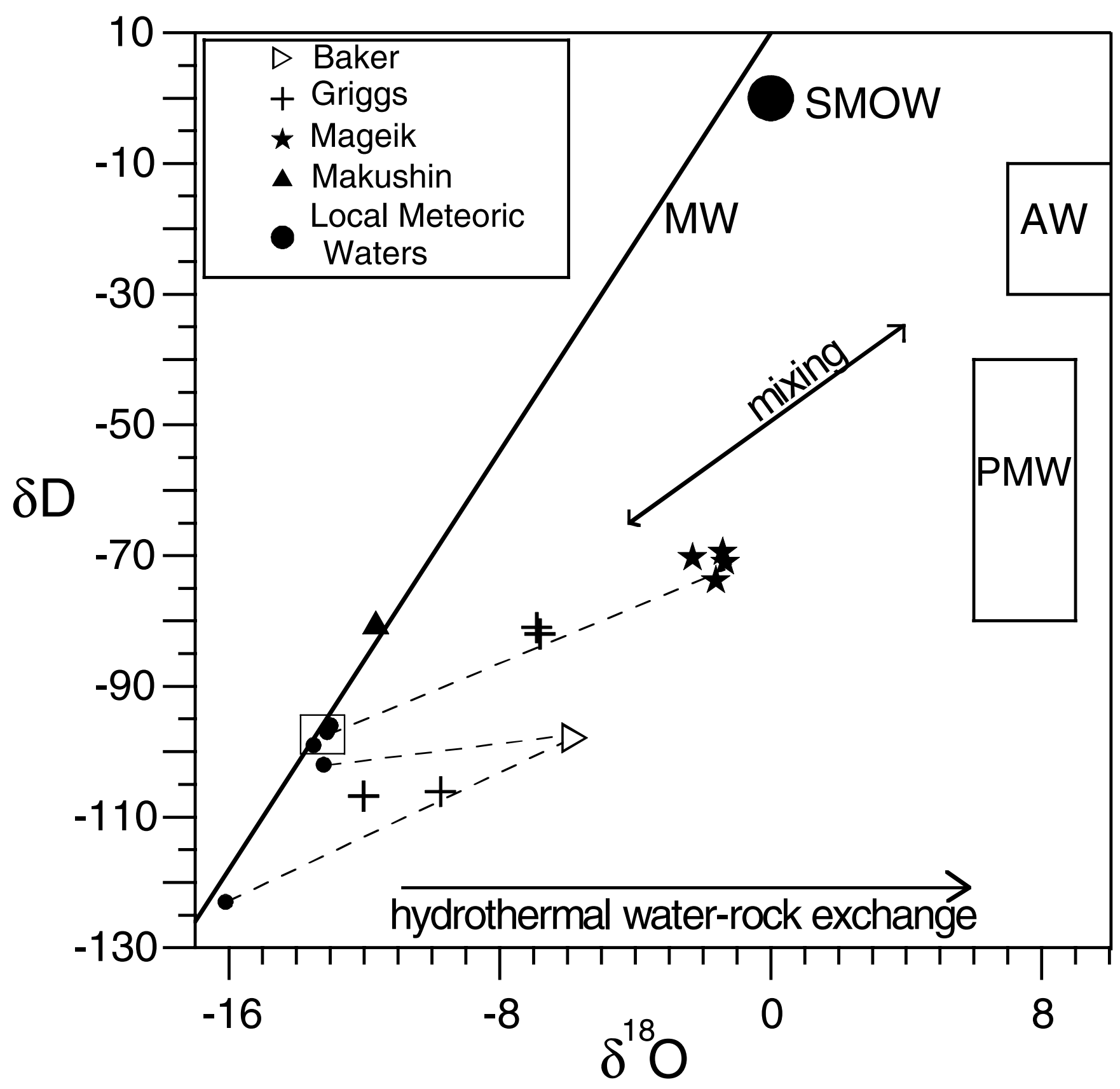

Figure 2. Plot of $\delta^{18} \mathrm{O}$ and $\delta \mathrm{D}$ values for condensed water from superheated fumaroles at Mounts Baker, Griggs (two highest $\delta \mathrm{D}$ points), and Mageik, and from boiling-point fumaroles at Mount Griggs (two lowest $\delta \mathrm{D}$ points) and Makushin. Dashed lines connect values for condensates at Mounts Baker and Mageik with their respective local meteoric waters. Plotted meteoric waters for Mount Mageik are from nearby sites (Keith and others, 1992); the two plotted meteoric waters for Mount Baker are estimates for the elevation of the sampling site and the summit derived from data from nearby Mount Rainier (Frank, 1995). Also shown for reference are the meteoric water (MW) line (Craig, 1961), standard mean ocean water (SMOW), the andesitic water (AW) box (Giggenbach, 1992), and the primary magmatic water (PMW) box (Sheppard and others, 1969). All data reported as per mil values relative to SMOW. 


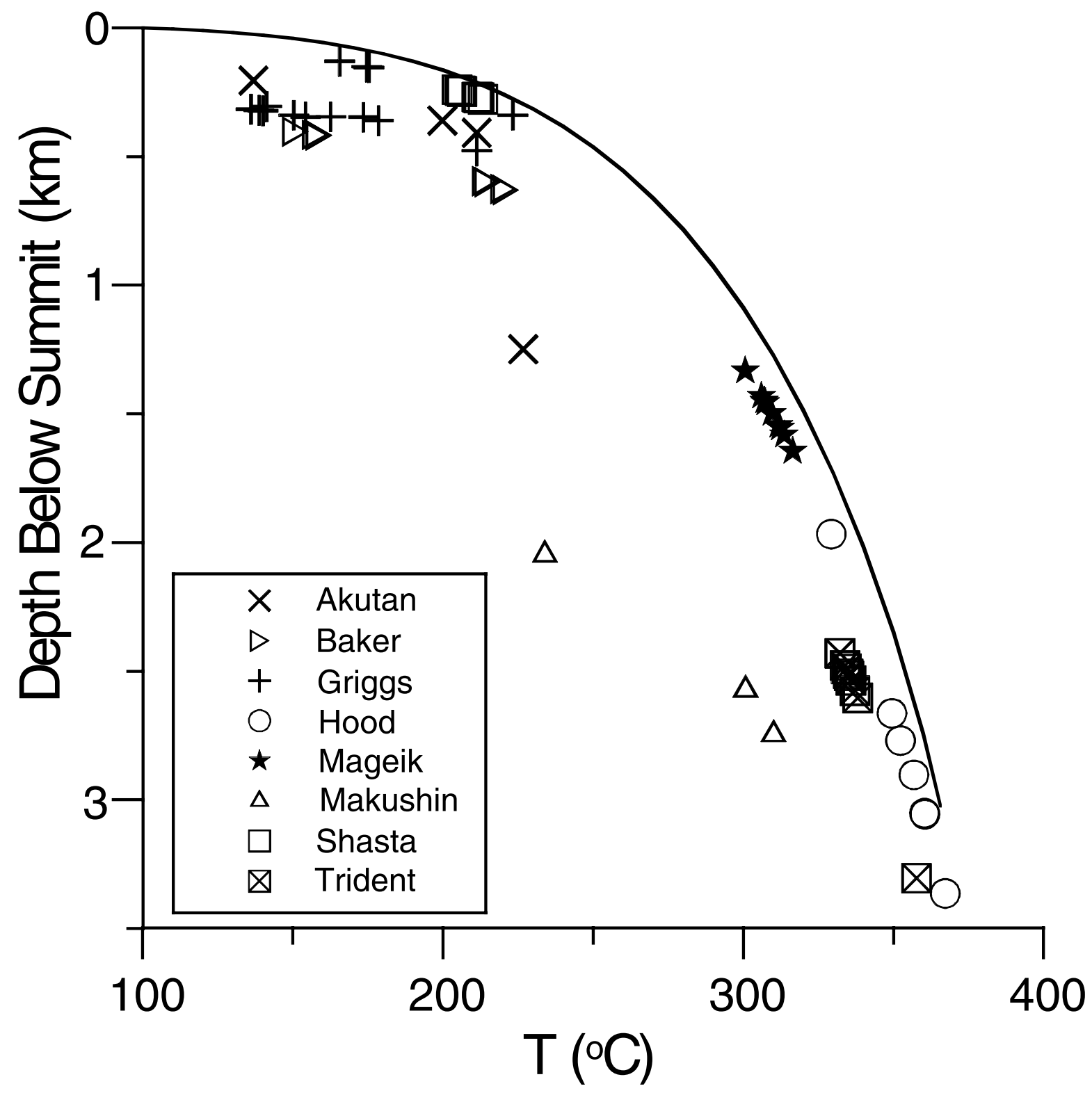

Figure 3. Diagram showing relation between reservoir temperature and inferred depth below summit for eight CRAA volcanoes. The boiling curve of water is shown for reference. Subsurface temperatures estimated by applying an empirical $\mathrm{H}_{2} \mathrm{~S}-\mathrm{H}_{2}-\mathrm{CH}_{4}-\mathrm{CO}_{2}$ geothermometer (D'Amore and Panichi, 1980) to the bulk-gas analyses. Depth below summit estimated by adding the boiling-curve depth for the geothermometer temperature to the elevation difference between the site and the summit. Note that summit-to-site elevation differences explain why the points plot beneath the boiling curve; the site-to-reservoir depth can be determined by extrapolating from the plotted points to the boiling curve with a vertical line. 


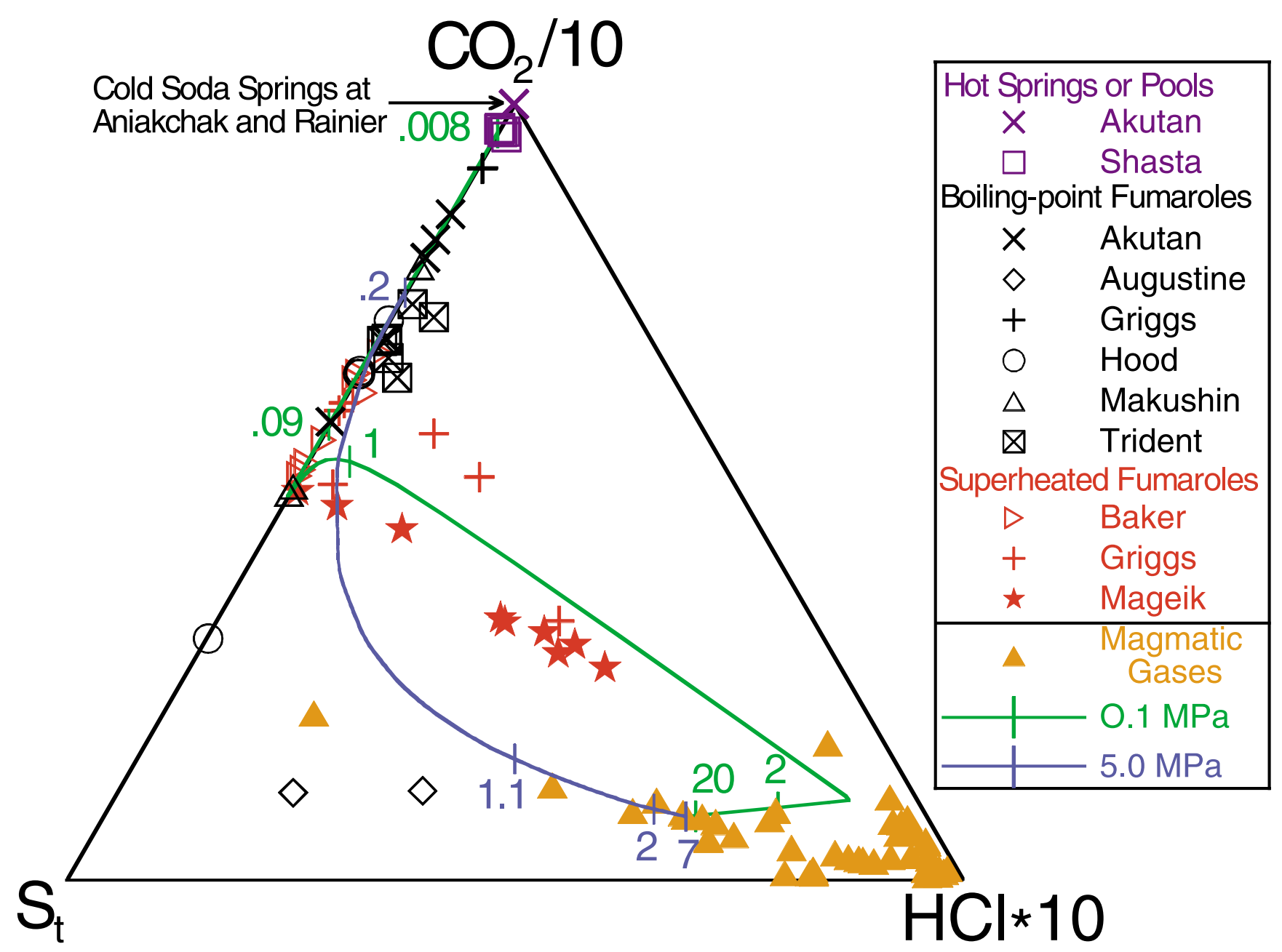

Figure 4. Ternary diagram of $\mathrm{CO}_{2}$, total $\mathrm{S}$, and $\mathrm{HCl}$ for gas discharges from CRAA volcanoes. Plot distinguishes between gases from cold soda springs (arrow near $\mathrm{CO}_{2} / 10$ apex), hot springs or pools (blue), boiling-point fumaroles (black), and superheated fumaroles (red). For comparison, we plot HTMG (orange) from convergent-plate volcanoes (Symonds and others, 1994). Green line shows evolution of "scrubbed" gas composition produced by injecting increasing amounts of hot magmatic gas into $1 \mathrm{~kg}$ of $25^{\circ} \mathrm{C}$ air-saturated water at $0.1 \mathrm{MPa}$ using a thermochemical modeling approach (Symonds and others, 2001). The injected gas, representative of convergent-plate $\mathrm{HTMG}$, is a $915^{\circ} \mathrm{C}$ gas from Merapi volcano, Indonesia (Le Guern and others, 1982). The numbers next to green line denote $\mathrm{kg}$ of gas added; as the calculations proceed, the mixture changes from liquid-plus-gas ( 0.008 to $1.7 \mathrm{~kg}$ of gas added; $\mathrm{T}$ $\left.=81^{\circ}-106^{\circ} \mathrm{C}\right)$ to gas-only $\left(1.7\right.$ to $100 \mathrm{~kg}$ of gas added; $\left.\mathrm{T}=106^{\circ}-895^{\circ} \mathrm{C}\right)$. Navy line shows "scrubbed" gas composition for the same reaction at 5.0 MPa (Symonds and others, 2001). 




Figure 5. Simplified box model of inputs (rectangles) and outputs (ellipses) of gases in a typical CRAA volcanic system during repose between eruptions (see text). Note zones of primary and secondary scrubbing as discussed in text. Thick and thin arrows indicate dominant and less important flow paths, respectively. Double arrows mark two-way flow paths. 